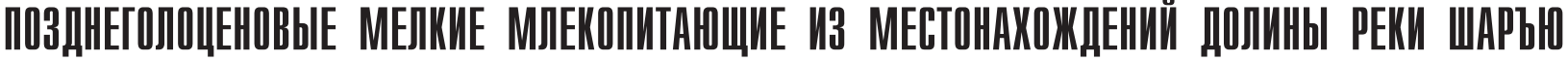 [ГРЯДА ЧЕРНЫШЕВА]
}

\author{
И. В. Кряжева ${ }^{1}$, Д. В. Пономарев ${ }^{1}$, Т. ван Кольфсхотен ${ }^{2}$, Й. ван дер Плихт ${ }^{2,3}$ \\ ${ }^{1}$ Институт геологии Коми НЦ УрОРАН, Сыктывкар, Россия; Innageologi@mail.ru, \\ 2Лейденский университет, Лейден, Нидерланды, \\ ${ }^{3}$ Центр изотопных исследований, Гронинген, Нидерланды
}

\begin{abstract}
Голоценовая история фауны мелких млекопитающих представляет интерес как пример трансформации сообществ под воздействием естественной динамики климата. Объектами изучения являлись 2720 щечных зубов мелких млекопитающих из местонахождений долины р. Шаръю (левый приток р. Усы), которые исследовались стандартными палеонтологическими методами. Для датирования ископаемых комплексов использовался ${ }^{14} \mathrm{C}$ УМС-метод. Местонахождения представляют собой зоогенные скопления с массовыми остатками позвоночных животных. В результате описаны две фазы развития микротериофауны гряды Чернышева: субатлантического и современного периодов. Установлено, что в субатлантическое время микротериофауна гряды Чернышева имела типичный лесной облик и была практически идентична синхронным сообществам мелких млекопитающих Приполярного Урала и сильно контрастировала с сообществами восточного макросклона Полярного Урала. Различия в видовых составах костных остатков грызунов из Шаръю-2 и Шаръю-3, очевидно, связаны с деятельностью разных видов пернатых хищников (дневных хищников и сов). Различия современных комплексов мелких млекопитающих гряды Чернышева и сопредельных территорий объясняется тафономическими причинами.
\end{abstract}

Ключевые слова: мелкие млекопитающие, поздний голоцен, гряда Чернышева, северо-восток европейской части России.

\section{LATE HOLOCENE SMALL MAMMALS FROM LOCALITIES OF SHARYU RIVER VALLEY (CHERNYSHEV'S RIDGE)}

\author{
I. V. Kryazheva1, D. V. Ponomarev1, T. van Kolfschoten², J. van der Plicht' ${ }^{2,3}$ \\ ${ }^{1}$ Institute of Geology of Komi SC UB RAS, Syktyvkar, \\ ${ }^{2}$ Leiden University, Leiden, Netherlands, \\ ${ }^{3}$ Center for Isotope Research, Groningen, Netherlands
}

The Holocene history of small mammal fauna is of interest as an example of transformation of communities under the natural changes of climate. Study object were 2720 molars of small mammals from localities in Sharyu River valley (left tributary of Usa River). Molars were studied by standard palaeontological techniques. ${ }^{14} \mathrm{C}$ AMS method was used for dating of fossil assemblages. All localities are zoogenic sites with abundant fossil remains of vertebrates. In the result, two phases of micromammalian fauna development in the Chernyshev's Ridge are described: Subatlantic and modern periods. It was revealed that typical taiga forest assemblages of small mammals inhabited the Chernyshev's Ridge during Subatlantic time. This fauna was nearly identical to micromammalian communities of the same interval in the Subpolar Urals but contrasted to tundra assemblages of the eastern slope of the Polar Urals. Species composition differences between Sharyu-2 and Sharyu-3 were caused by the hunting activity of different species of avian predators (diurnal raptors and owls). Alternations between recent micromammalian assemblages of the Chernyshev's Ridge and communities of adjacent territories are linked to differences in taphonomy.

Keywords: small mammals, Late Holocene, Chernyshev's ridge, northeastern part of European Russia.

\section{Введение}

Исследования быстро эволюционировавших мелких млекопитающих являются одним из перспективных направлений в палеотериологии. Во всем мире они используются в качестве руководящих ископаемых и индикаторов определенных климатов и ландшафтов при реконструкции природной обстановки прошлого. Их остатки распространены в континентальных отложениях Палеарктики и весьма многочисленны в пещерных местонахождениях Урала.

В результате деятельности хищников и в редких случаях человека в карстующихся палеозойских породах Урала и его предгорий сформировались захоронения костных остатков позвоночных. Пещерные зоогенные скопления костных остатков занимают одно из первых мест по информативности среди других типов захоронений остатков плейстоценовых и голоценовых позвоночных. Остеологический материал накапливается в них, как правило, или на месте гибели животного, или вблизи него, причем ископаемый комплекс воспроизводит видовой состав исходного естественного сообщества в максимально возможной полноте [17, 18].
В данной работе приводятся результаты изучения трех местонахождений гряды Чернышева, расположенных на реке Шаръю (левый приток в нижнем течении р. Усы, Усинск, Республика Коми) (рис. 1). Гряда Чернышева оставалась неизученным районом в отношении истории микротериофауны, выявлению специфики которой посвящена настоящая работа.

\section{Материал и методы}

Местонахождение Шаръю-1 (6609.186' с. Ш., $58^{\circ} 43.792^{\prime}$ в. д.) расположено на правом берегу реки, в 1.5 км ниже по течению от геологического памятника природы Окно, в скальном выходе известняков силура, и представляет собой небольшой грот высотой 1 м, шириной 0.8 м и глубиной 2 м (рис. 1).

Разрез рыхлых отложений состоит из двух слоев, представленных алевритовыми и суглинистыми отложениями (рис. 2). Всего из отложений грота определенно 1024 зуба мелких млекопитающих (см. таблицу). Радиоуглеродная датировка, сделанная по костям грызунов из слоя 2 (глубина 17 см), показала возраст 


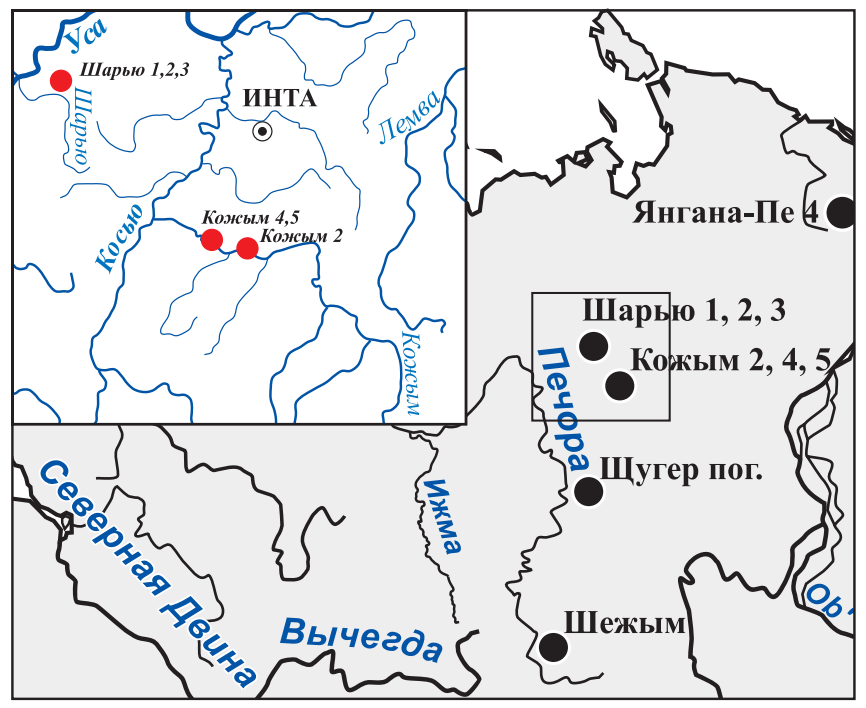

Рис.1. Карта местонахождений позднеголоценовых мелких млекопитающих

Fig. 1. Locations of Late Holocene small mammals

$(1510 \pm 35)$ некалиброванных л. н. (GrA-66862), что приходится на поздний голоцен (субатлантик).

В местонахождении Шаръю-1 встречены останки мелких птиц, зайцеобразных, насекомоядных, грызунов и рыб с преобладанием последних. Раздробленность костей невысокая.

Местонахождение Шаръю-2 (66이.152' с. ш., $58^{\circ}$ 43.952 ' в. д.) расположено в 200 м выше по течению от грота Шаръю-1 на высоте 30 м от уреза воды. Оно
Количество щечных зубов и соотношение остатков (в скобках, \%) мелких млекопитающих из местонахождений р. Шаръю

Quantity of cheek teeth and ratio of remains (in brackets, \%) of small mammals from locations near Sharyu River

\begin{tabular}{l|c|c|c}
\hline \multicolumn{1}{c|}{ Вид / Species } & $\begin{array}{c}\text { Шаръю-1 } \\
\text { Sharyu-1 }\end{array}$ & $\begin{array}{c}\text { Шаръю-2 } \\
\text { Sharyu-2 }\end{array}$ & $\begin{array}{c}\text { Шаръю-3 } \\
\text { Sharyu-3 }\end{array}$ \\
\hline Sciurus vulgaris & $1(0.1)$ & - & $64(11.9)$ \\
Sicista betulina & $3(0.3)$ & - & - \\
Ondatra zibethicus & - & - & $18(3.4)$ \\
Clethrionomys sp. & $344(33.6)$ & $372(32)$ & $60(11.2)$ \\
Dicrostonyx sp. & $7(0.7)$ & - & - \\
Lemmus sibiricus & $14(1.4)$ & - & - \\
Myopus schisticolor & $97(9.7)$ & - & - \\
Arvicola amphibius & $152(14.8)$ & - & $130(24.3)$ \\
Microtus oeconomus & $259(25.3)$ & $54(4.7)$ & $21(3.9)$ \\
Microtus agrestis & $147(14.3)$ & $735(63.3)$ & $242(45.2)$ \\
Вceго / Total & 1024 & 1161 & 535
\end{tabular}

представляет собой скальный выступ под обитаемым гнездом длиной 1 м и глубиной 0.7 м (рис. 4, а). На протяжении всего полевого сезона с этого выступа было собрано 92 погадки, из которых в лаборатории было извлечено и определено 1160 зубов грызунов (см. таблицу).

Местонахождение Шаръю-3 (66웅.871' с. ш., 58 44.654 ' в. д.) расположено на левом берегу р. Шаръю, в 2 км выше по течению от устья р. Дурной, в скальном
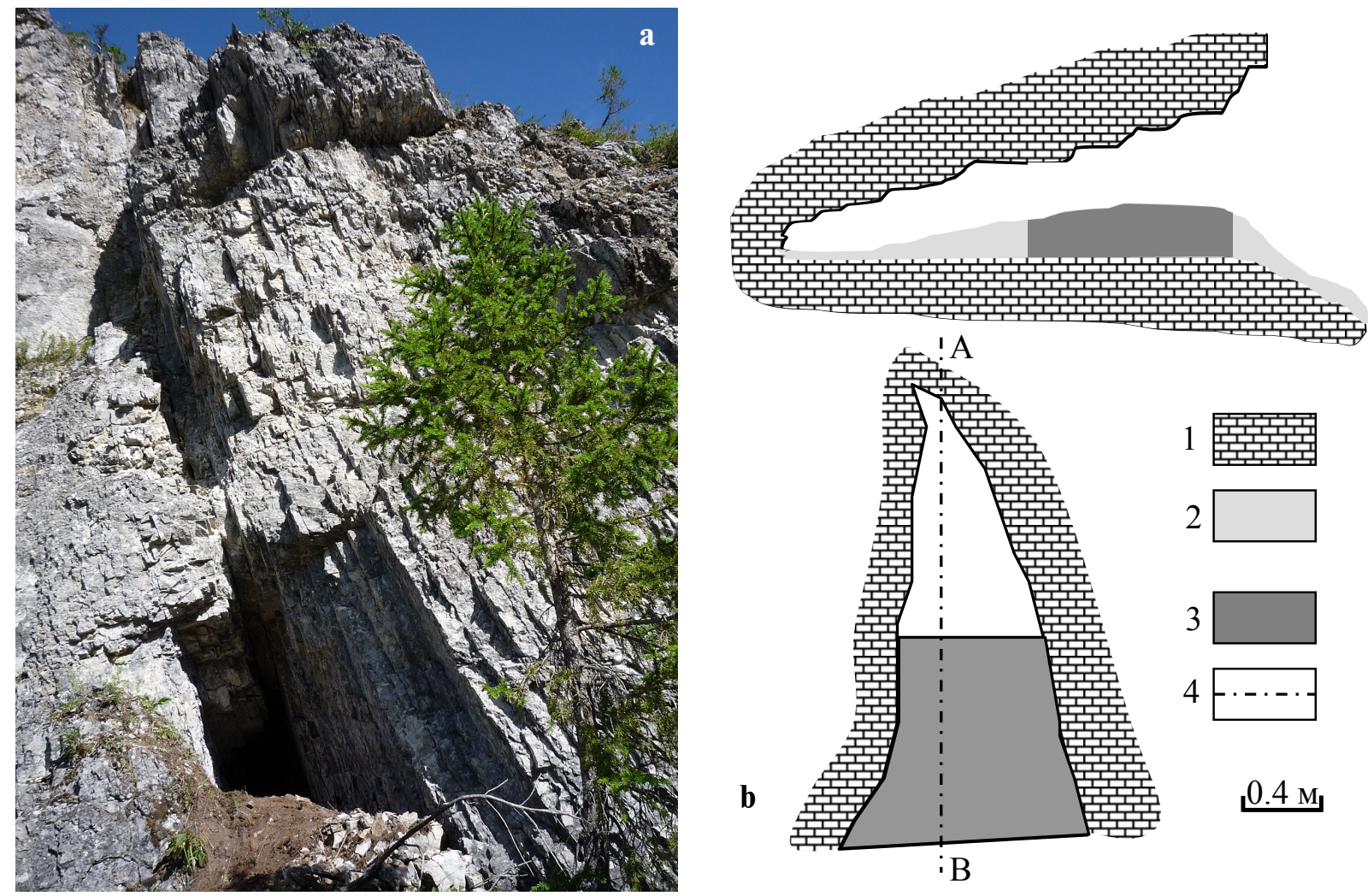

Рис. 2. Общий вид (а) и план-схема (b) грота Шаръю-1: 1 - коренная порода, 2 - четвертичные отложения, 3 - раскоп, 4 - линия продольного профиля АВ

Fig. 2. General view (a) and scheme (b) of grotto Sharyu-1: 1 - bedrock, 2 - Quarternary deposits, 3 - pit, 4 - longitudinal profile AB 
a

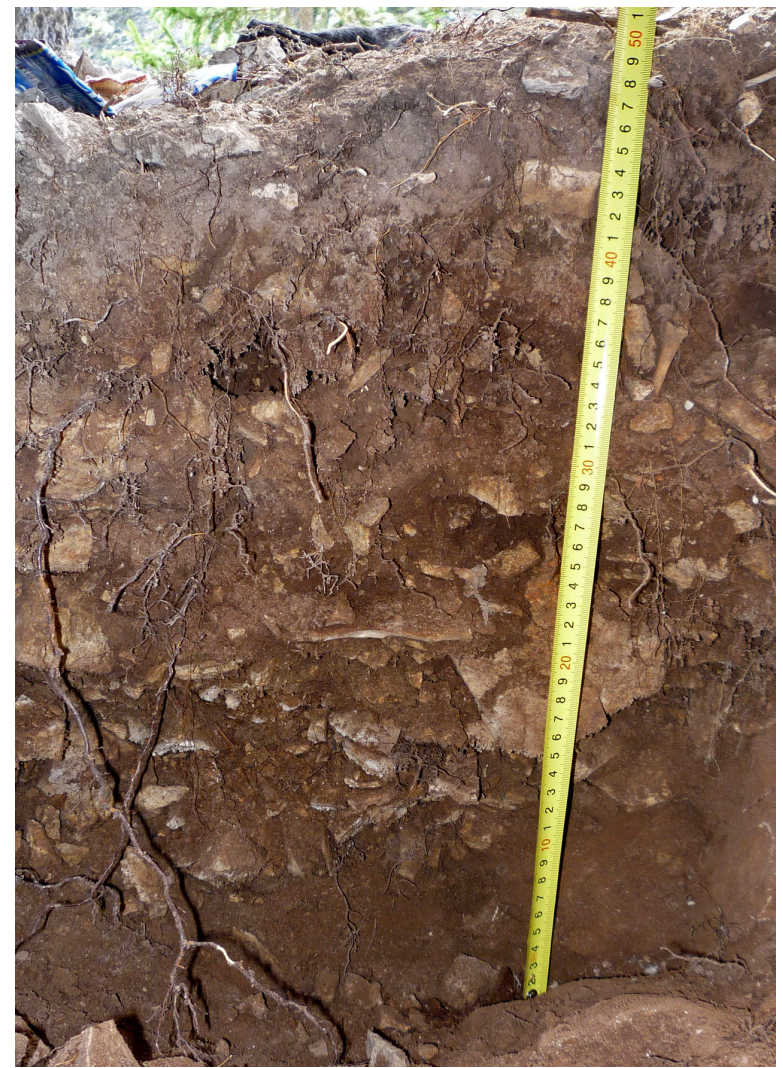

$0,5 \mathrm{M}$

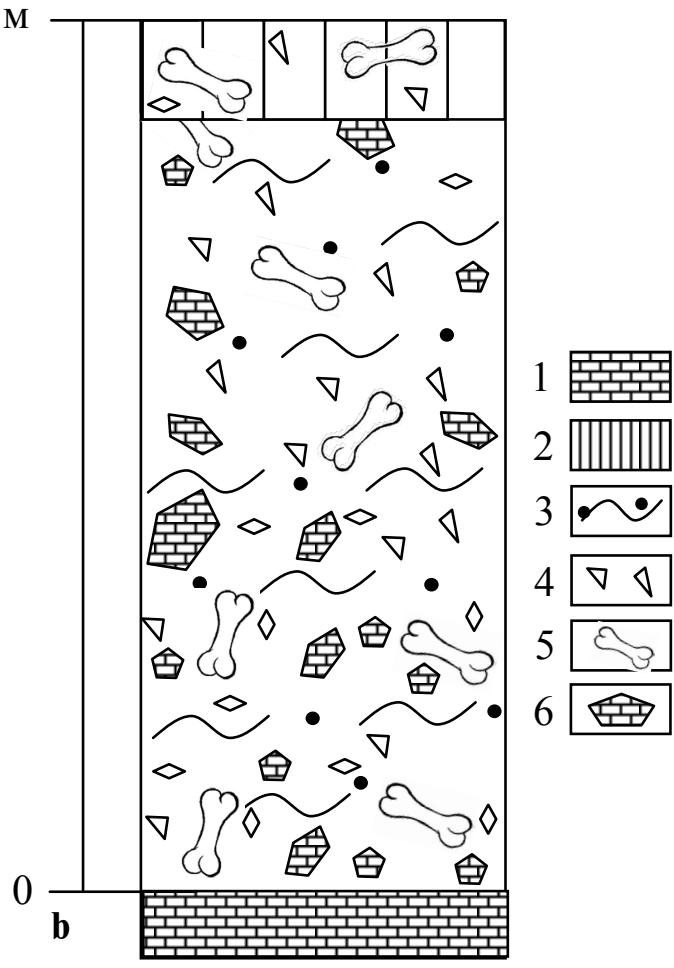

Рис. 3. Фото (a) и схематический геологический разрез (b) рыхлых отложений грота Шаръю-1: 1 - коренная порода (известняк), 2 - почвенно-растительный слой (ПРС), 3 - суглинок, 4 - неокатанные обломки известняка $(0.5-3$ см), 5 - костные остатки, 6 - глыбы известняка

Fig. 3. Photo (a) and schematic section (b) of loose sediments of grotto Sharyu-1: 1 - bedrock (limestone), 2 - top soil, 3 - loam, $4-$ limestone debris $(0.5-3 \mathrm{~cm}), 5-$ bone remains, 6 - limestone blocks
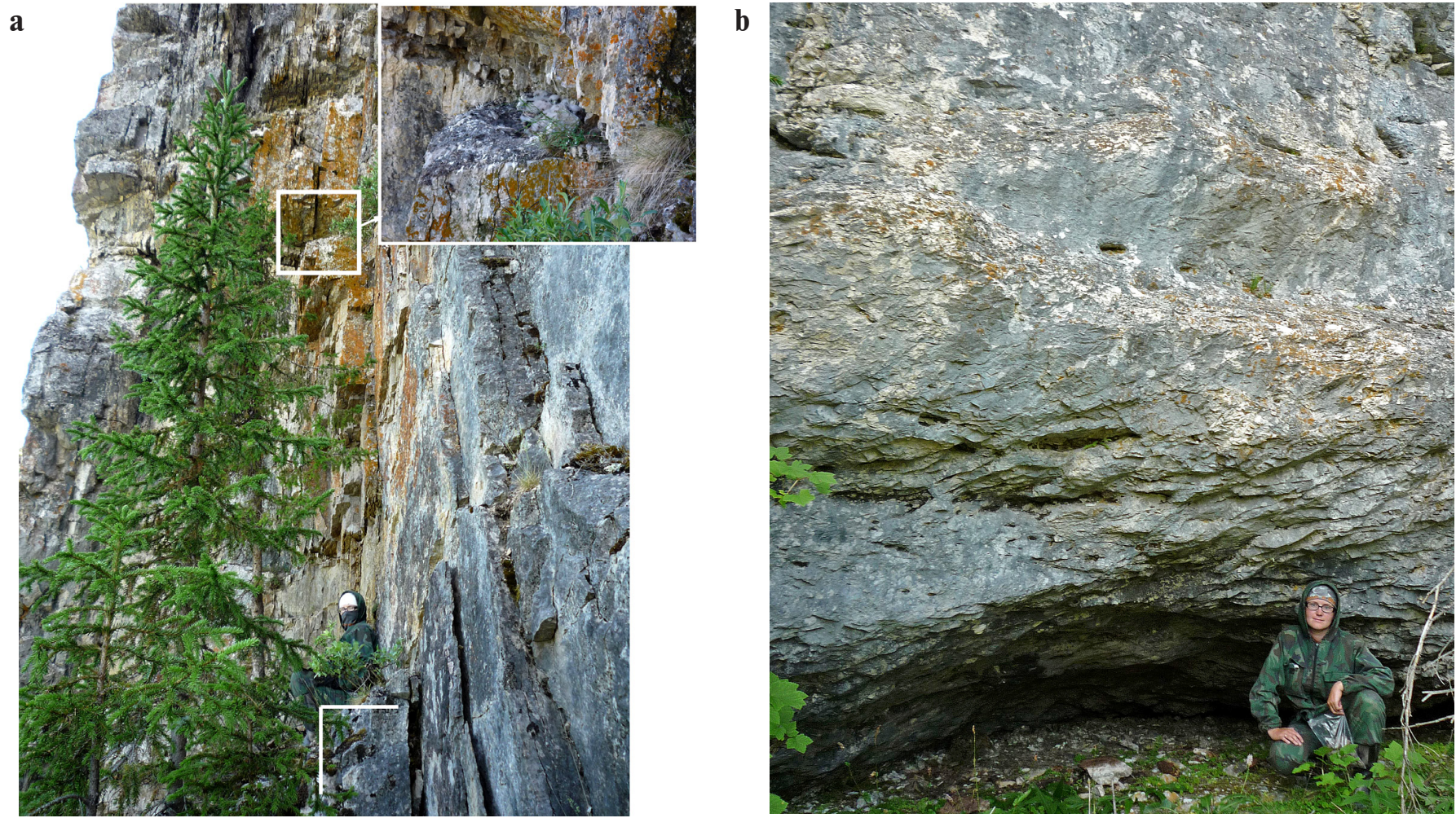

Рис. 4. Местонахождения Шаръю-2 (а) и Шаръю-3 (b)

Fig. 4. Locations Sharyu-2 (a) and Sharyu-3 (b) 
выходе известняков карбона на высоте 20 м от уреза воды. Оно представляет собой небольшую нишу (рис. 4, б), в которой было обнаружено скопление погадок. Рыхлые отложения ниши представлены почвеннорастительным слоем мощностью менее 5 см. Собрано 54 погадки, из которых в лаборатории было извлечено и определено 535 зубов грызунов (см. таблицу). Судя по наличию остатков ондатры, интродуцированной в Республике Коми в 1930-е гг., возраст комплекса остатков не превышает 80 лет [21].

Раскопки в гроте Шаръю-1 проводились по стандартным методикам [13-15]. Рыхлые отложения вскрывались условными горизонтами мощностью не более 10 см. Извлечение костных остатков млекопитающих производилось при помощи ручной промывки вмещающей породы на ситах с размером ячеи $0.8-$ $1.0 \mathrm{MM}$.

Полученная смесь костей и обломков породы высушивалась и из нее вручную отбирались остатки позвоночных.

Ввиду того, что в роде серых полевок наиболее диагностичны только первые нижние коренные зубы, для расчета каждого вида полевок все зубы, определенные как Microtus sp., распределялись по видам в соответствии с распределением первых нижних коренных. Морфологически сходные виды, такие как полевка Миддендорфа - темная полевка и лесной лемминг - сибирский лемминг, диагностика которых представляет определенные трудности, разделялись нами по методике, описанной Н. Г. Смирновым с соавторами [19]. Моляры трех видов рода Clethrionomys идентифицировались согласно методу, предложенному А. В. Бородиным [4].

УМС ${ }^{14} \mathrm{C}$-датировка по костям грызунов была выполнена Й. ван дер Плихтом (Центр изотопных исследований университета г. Гронинген, Нидерланды).

\section{Результаты и их обсуждение}

Самый древний ископаемый комплекс (субатлантик), обнаруженный в долине реки Шаръю, происходит из отложений грота Шаръю-1. Здесь были найдены красная и рыжая полевки (вместе $33.9 \%$ ), полевкаэкономка (21.5\%), водяная полевка (14.8\%), темная полевка (11.2\%), лесной (6.3\%), сибирский (1.4\%) и копытный (0.7 \%) лемминги (рис. 5).

На севере Урала сообщества субатлантика известны также из местонахождений Кожым-2 и -4 (западный склон Приполярного Урала) и Янгана-Пе-4 (восточный макросклон Полярного Урала). В ископаемом комплексе из грота Кожым-2 с датировкой (1655 \pm 35$)$ некалиброванных л. н. (GrA-49355) были найдены водяная полевка (29.3\%), красная и рыжая полевки $(39.5 \%)$, темная полевка (15.6\%), полевка-экономка (5\%), узкочерепная полевка $(2.7 \%)$, сибирский (5\%) и лесной $(2.9 \%)$ лемминги [7, 10, 11].

В сообществе из грота Кожым-4 (датировка $(1620 \pm 30)$ некалиброванных л. н. GrA-66465) были определены красная и рыжая полевки (вместе $34.1 \%$ ), темная полевка (24.3\%), водяная полевка (16.2\%), полевка-экономка (11.1\%), лесной (10.8\%), сибирский $(3 \%)$ и копытный $(0.5 \%)$ лемминги $[9,10]$.

В фауне из слоя 2 Янгана-Пе-4 с датировкой (1720 \pm 120$)$ некалиброванных л. н. найдены сибир-

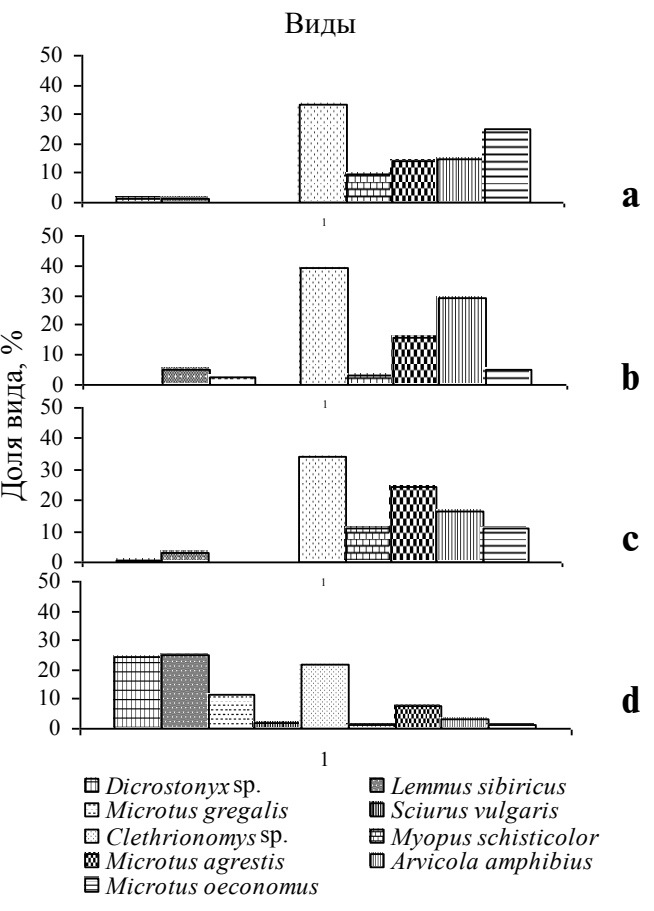

Рис. 5. Соотношение долей остатков мелких млекопитающих (в процентах) в гроте Шаръю-1 (a), слое 2 Кожым-2 (b) и Кожым-4 (c) и Янгана-Пе-4 (d)

Fig. 5. Ratio of small mammals remains (percentage) in grotto Sharyu-1 (a), layer Kozhym-2 (b) and Kozhym-4 (c) and Yangana-Pe (d)

ский $(25.2 \%)$ и копытный $(24.5 \%)$ лемминги, узкочерепная полевка (11.8\%), рыжие полевки (21.6\%), темная полевка (7.8\%), водяная полевка (3\%), белка (2\%), лесной лемминг (1.6\%) и единичные зубы полевки-экономки [12].

По палинологическим данным, в это время на равнинной территории Республики Коми и в ее горной части получили развитие темнохвойные леса из ели со значительной примесью сосны. Отличительной чертой того времени для северо-востока европейской части России являлся расцвет еловых лесов, чему способствовало потепление - так называемый малый климатический оптимум $[5,16]$. Потепление климата привело к формированию северотаежных еловых лесов с примесью сосны и березы и на Полярном Урале (хребет Енганепэ), о чем свидетельствуют сохранившиеся с начала среднего субатлантического периода реликтовые образования чернично-зеленомошных ельников [6].

Из представленных материалов видно, что в субатлантическое время микротериофауна гряды Чернышева имела типичный лесной облик и была практически идентична сообществам мелких млекопитающих Приполярного Урала, что хорошо согласуется с данными по истории растительности и ландшафтов северо-востока Европы в это время. Различия в составе фауны мелких млекопитающих гряды Чернышева и восточного макросклона Полярного Урала связаны, скорее всего, с меридиональным градиентом природных условий.

Комплексы остатков мелких млекопитающих из погадок Шаръю-2 и Шаръю-3 дают представление о современной фауне района исследований. 
В сообществе Шаръю-2 были найдены остатки мелких млекопитающих только из микроразмерной группы - темная полевка (63.3\%), красная и рыжая полевки (вместе 32 \%) и полевка-экономка (4.7 \%). В фауне Шаръю-3 видовой состав более разнообразный - темная полевка (45.2\%), водяная полевка (24.3\%), белка (11.9\%), красная и рыжая полевки (11.2\%), полевка-экономка (3.9\%) и ондатра $(3.4 \%)$. Такие существенные различия в составе одновозрастных и близко расположенных друг к другу локальных фаун связаны, скорее всего, с избирательностью отлова разными видами пернатых хищников. Это подтверждает и размер погадок в Шаръю-2 - от 2 до 4 см, в то время как в Шаръю-3 погадки крупнее - от 4 до 6 см (рис. 6). Также это подтверждается количеством и сохранностью костного материала. Погадки из Шаръю-2 принадлежат дневным пернатым хищникам - это было установлено в первую очередь по внешнему виду птенцов в гнезде (рис. 3, а), а во-вторых, по количеству и сохранности костного материала в погадках $[8,23]$. Несмотря на маленький размер погадок (от 2 до 4 см), в них содержались зубы от двух и более особей, также было отмечено, что эмаль на зубах частично растворена и эродирована (зубы Clethrionomys), а количество костей относительно небольшое.
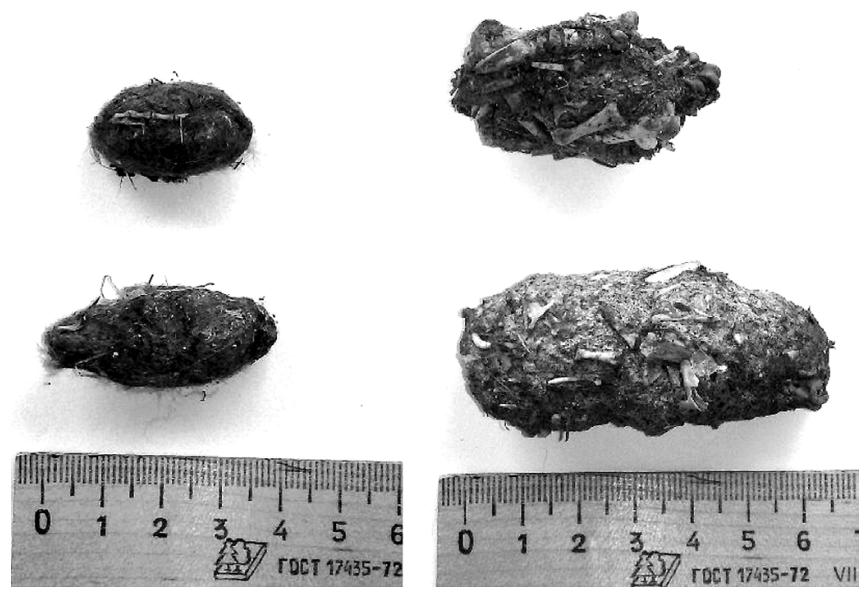

Рис. 6. Погадки из местонахождений Шаръю-2 (а) и Шарью-3 (b)

Fig. 6. Pellets from locations Sharyu-2 (a) and Sharyu-3 (b)

В погадках из Шаръю-3 содержались костные остатки от одной, реже двух особей. Эмаль на зубах сохранила гладкость и блеск (зубы Clethrionomys, Sciurus vulgaris и Ondatra zibethicus). Некоторые погадки содержали целые части черепов с зубами (Arvicola amphibius, Clethrionomys, Microtus oeconomus и Microtus agrestis) и сочлененные элементы скелета. Все эти признаки указывают на то, что эти погадки, скорее всего, принадлежат ночным пернатым хищникам [8, 23].

В современной фауне Приполярного и Северного Урала наблюдается похожая картина (рис. 7). В местонахождении Кожым-5 [9, 10] были обнаружены темная полевка (37.6 \%), водяная полевка (19.9\%), полевка-экономка (19.5\%), лесной лемминг (12.2\%), красная и рыжая полевки (вместе $9.9 \%)$, белка $(0.5 \%)$ и
Виды

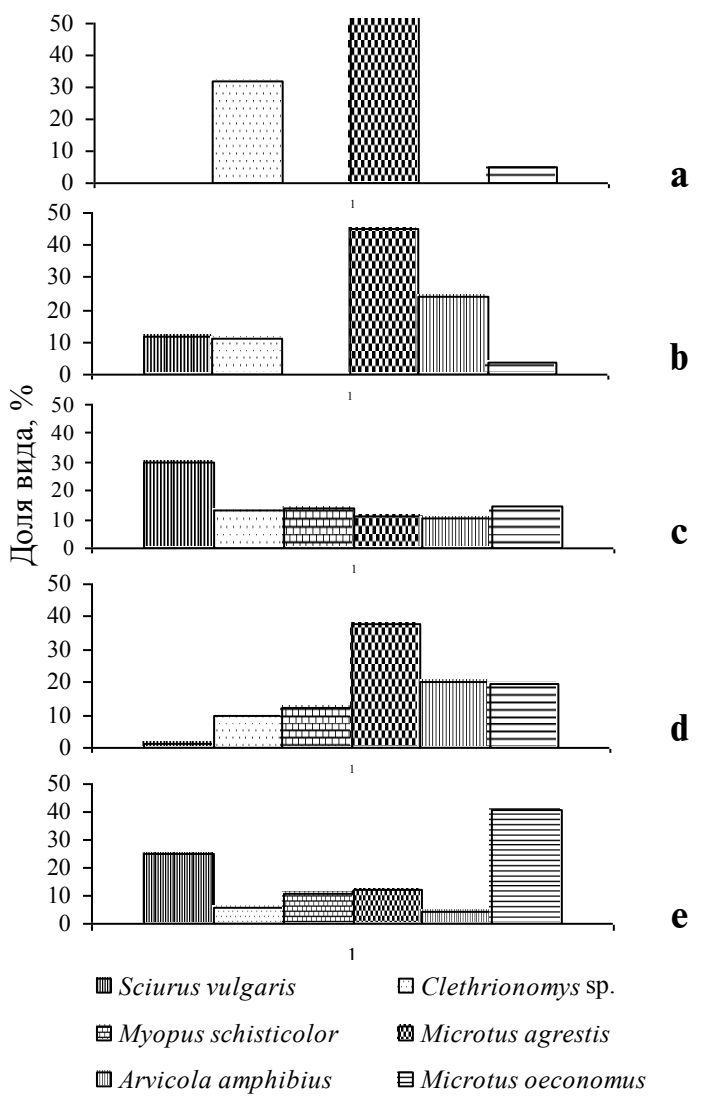

Рис. 7. Соотношение долей остатков мелких млекопитающих (в процентах) в сообществах Шаръю-2 (а), Шаръю-3 (b), Шежым (c), Кожым-5 (d) и Щугер (e)

Fig. 7. Ratio of small mammals remains (percentage) in community Sharyu-2 (a), Sharyu-3 (b), Shezhym-5 (d) and Shchuger (e)

ондатра (0.4 \%). В погадках, собранных в долине реки Щугер [11], были определены полевка-экономка (40.4\%), белка (25\%), темная полевка (12.4\%), лесной лемминг (11\%), красная и рыжая полевки (вместе $6 \%$ ) и водяная полевка (4.4\%). В местонахождении Шежым преобладают остатки белки (29.8 \%), примерно в равных долях (по 8-11\%) представлены остатки водяной, темной полевок, полевки-экономки, лесного лемминга. Полевки трех видов Clethrionomys вместе составили $13 \%$ [20].

Интересен и тот факт, что в погадках, найденных в долине реки Шаръю, не было обнаружено остатков лесного лемминга, в то время как в сообществе мелких млекопитающих Приполярного и Северного Урала на их долю приходится более 10 \% от всех остатков. Лесной лемминг населяет таежную зону: ельники разного типа, сосново-еловые леса, а также обитает в смешанных лесах и ивняковых зарослях по берегам рек [22]. Такие биотопы в настоящее время наблюдаются на Приполярном, Северном Урале и на территории гряды Чернышева [1-3]. Поэтому можно предположить, что полное отсутствие лесного лемминга в локальных ориктоценозах гряды Чернышева связано с избирательностью пернатых хищников при отлове своих жертв. 


\section{Выводы}

В результате исследований было установлено, что в субатлантическое время микротериофауны гряды Чернышева и Приполярного Урала были практически идентичными и имели лесной облик, характерный для всех позднеголоценовых сообществ северо-востока Европы, что неудивительно, учитывая географическую близость районов. Эти фауны отличались от сообществ восточного макросклона Полярного Урала, которые имели типичный тундровый состав и экологическую структуру. В современных (последние 80 лет) комплексах мелких млекопитающих гряды Чернышева и сопредельных территорий наблюдаются явные различия, имеющие тафономическую природу.

Авторы благодарны сотруднику Института геологии Коми НЦ УрО РАН А. А. Кряжеву за помощь при проведении полевых работ.

Работа выполнена при частичной поддержке гранта РФФИ 16-35-00116 мол_а и Программы фундаментальных исследований УрО РАН №15-18-5-38.

\section{Литература}

1. Атлас Коми АССР. М., 1964. 112 с.

2. Биоразнообразие водных и наземных экосистем бассейна реки Кожым (северная часть национального парка «Югыд ва») / Отв. редактор Е. Н. Патова. Сыктывкар, 2010. 192 c.

3. Бобрецов А. В., Лукьянова Л. Е., Порошин Е. А. Структура и динамика населения мелких млекопитающих предгорий Северного Урала // Закономерности зональной организации комплексов животного населения Европейского Северо-Востока. Сыктывкар, 2005. С. 5-20. (Тр. Коми научного центра УрО Российской АН, № 177).

4. Бородин А. В. Определитель зубов полевок Урала и Западной Сибири (поздний плейстоцен - современность). Екатеринбург: УрО РАН, 2009. 100 с.

5. Голубева Ю. В. Климат и растительность голоцена на территории республики Коми // Литосфера. 2008. № 2. C. $124-132$.

6. Дымов А. А., Загирова С. В., Марченко-Вагапова Т. И. Формирование еловых биогеоценозов на Полярном Урале // Лесоведение. 2011. № 5. С. 12-23.

7. Кряжева И. В. Мелкие млекопитающие позднего плейстоцена и голоцена Приполярного Урала: Автореф. дис. ... канд. геол.-минер. наук. Сыктывкар. 2012. 18 с.

8. Кряжева И. В. Особенности накопления и сохранности костных остатков мелких млекопитающих в карстовых полостях Приполярного Урала // Вестник Института геологии. Сыктывкар. 2012. № 6. С. 8-10.

9. Кряжева И. В. Позднеголоценовые мелкие млекопитающие из новых местонахождений реки Кожым (Приполярный Урал) // Современная палеонтология: классические и новейшие методы. Москва, 2013. М.: ПИН РАН. C. 24.

10. Кряжева И. В., Пономарев Д. В. Микротериофауна западного склона Приполярного Урала в позднем плейстоцене и голоцене (р. Кожым) // Вестник Института геологии. Сыктывкар. 2014. № 5. С. 3-9.

11. Кряжева И. В., Пономарев Д. В., Т. ван Кольфсхотен, Х. ван дер Плихт. История формирования современных сообществ микромаммалий Приполярного Урала // Экология. 2012. № 6. С. 434-441.
12. Кузьмина Е. А., Головачев И. Б. Позднеголоценовые грызуны из местонахождения Ян-гана-Пе-4 на Полярном Урале // Развитие идей академика С. С. Шварца в современной экологии: Материалы конф. Екатеринбург, 1999. C. $100-104$

13. Методическое руководство по изучению и геологической съемке четвертичных отложений. М.: Госгеолтехиздат, 1955. Ч. 2. 486 с.

14. Методическое руководство по изучению и геологической съемке четвертичных отложений. Л.: Недра, 1987. $308 \mathrm{c}$.

15. Методы изучения осадочных пород. М.: Госгеолтехиздат, 1957. Т. 2. 564 с.

16. Никифорова Л. Д. Динамика ландшафтных зон голоцена северо-востока европейской части СССР // Развитие природы территории СССР в позднем плейстоцене и голоцене. М.: Наука, 1982. С. 154-162.

17. Оводов Н. Д. Палеофаунистическое изучение пещер // Общие методы изучения истории современных экосистем. М.: Наука, 1979. С. 102-128.

18. Смирнов Н. Г. Динамика видов и их комплексов как предмет исследований исторической экологии // Экология. 2006. № 6. С. 452-456.

19. Смирнов Н. Г., Головачев И. Б., Бачура О. П., Кузнецова И. А., Чепраков М. И. Сложные случаи определения зубов грызунов из отложений позднего плейстоцена и голоцена тундровых районов Северной Евразии // Материалы по истории и современному состоянию фауны севера Западной Сибири: Сб. науч. тр. Челябинск, 1997. C. $60-90$.

20. Смирнов Н. Г., Садыкова Н. О. Источники погрешностей при фаунистических реконструкциях в четвертичной палеозоологии // Четвертичная палеозоология на Урале. Екатеринбург: Изд. Урал. ин-та, 2003. С. 98-115.

21. Турьева В. В. Эколого-фаунистический обзор мелких млекопитающих западного склона Приполярного Урала // Животный мир западного склона Приполярного Урала (Труды Коми филиала АН СССР). Сыктывкар. 1977. С. 44101.

22. Фауна Европейского Северо-Востока России. Млекопитающие. СПб.: Наука, 1994. Т. II. ч. 1. 280 с.

23. Mayhew D. F. Avian predators as accumulators of fossil mammal material // Boreas. 1977. T. 6. № 1. P. 25-31.

\section{References}

1. Atlas of Komi ASSR. Moscow, 1964, 112 pp.

2. Bioraznoobrazie vodnyh $i$ nazemnyh ekosistem basseina reki Kozhym (severnaya chast natsionalnogo parka "Yugyd va") (Biodiversity of water and land ecosystems of the Kozym River basin (northern part of national park Yugydva)). Ed. E. N. Patova. Syktyvkar, 2010, 192 pp.

3. Bobretsov A. V., Lukyanova L. E., Poroshin E. A. Struktura i dinamika naseleniya melkih mlekopitayuschih predgorii Severnogo Urala (Structure and dynamics of population of small mammals of Northern Urals). In: Zakonomernosti zonalnoi organizatsii kompleksov zhivotnogo naseleniya evropeiskogo Severo-Vostoka (Regularities of zonal organization of complexes of animal population of European North-East). Syktyvkar, 2005, pp. 5-20.

4. Borodin A. V. Opredelitel zubov polevok Urala i Zapadnoi Sibiri (pozdnii pleistotsen-sovremennost) (Guide for teeth of voles from Urals and Western Siberia (Late Pleistocene-modern times)). Ekaterinburg, UB RAS, 2009, 100 pp. 
5. Golubeva Yu. V. Klimat i rastitelnost golotsena na territorii respubliki Komi (Climate and vegetation in Holocene in Komi Republic). Litosfera, 2008, No. 2, pp. 124-132.

6. Dymov A. A., Zagirova S. V., Marchenko-Vagapova T. I. Formirovanie elovyh biogeotsenozov na Polyarnom Urale (Formation of fur biogeocenoses in Polar Urals). Lesovedenie, 2011, No. 5, pp. 12-23.

7. Kryazheva I. V. Melkie mlekopitayuschie pozdnego pleistotsena i golotsena Pripolyarnogo Urala (Small mammals in Late Pleistocene and Holocene in Subpolar Urals). Extended abstract of $\mathrm{PhD}$ dissertation (geology and mineralogy). Syktyvkar, 2012, $18 \mathrm{pp}$.

8. Kryazheva I. V. Osobennosti nakopleniya i sohrannosti kostnyh ostatkov melkih mlekopitayuschih $v$ karstovyh polostyah Pripolyarnogo Urala (Special features of accumulation and preservation of bone remnants of small mammals in carst voids of Subpolar Urals). Vestnik of Institute of geology. Syktyvkar, 2012, No. 6 , pp. $8-10$.

9. Kryazheva I. V. Pozdnegolotsenovye melkie mlekopitayuschie iz novyh mestonahozhdenii reki Kozhym (Pripolyarnyi Ural) (Late Holocene small mammals from new locations of Kozhym River (Subpolar Urals). In: Sovremennaya paleontologiya: klassicheskie i noveishie metody (Modern paleotology: classical and newest methods). Moscow, 2013

10. Kryazheva I. V., Ponomarev D. V. Mikroteriofauna zapadnogo sklona Pripolyarnogo Urala v pozdnem pleistotsene i golotsene (r.Kozhym) (Microteriofauna of western slope of Subpolar Urals in Late Pleistocene and Holocene (Kozym river)). Vestnik of Institute of geology. Syktyvkar, 2014, No. 5, pp. 3-9.

11. Kryazheva I. V., Ponomarev D. V., T. van Kol'fshoten, H. van der Pliht Istoriya formirovaniya sovremennyh soobschestv mikromammalii Pripolyarnogo Urala (History of formation of modern communities of micromammals of Subpolar Urals). Ekologiya. 2012, No. 6, pp. 434-441.

12. Kuzmina E. A., Golovachev I. B. Pozdnegolotsenovye gryzuny iz mestonahozhdeniya Yan-gana-Pe-4 na Polyarnom Urale (Late Holocene gnawers from location Yanganape in Subpolar Urals). Proceedings, Ekaterinburg, 1999, pp. 100-104.

13. Metodicheskoe rukovodstvo po izucheniyu i geologicheskoi semke chetvertichnyh otlozhenii (Guide to study and geological survey of Quarternary deposits). Moscow, Gosgeoltehizdat, 1955, Ch. 2, 486 pp.

14. Metodicheskoe rukovodstvo po izucheniyu i geologicheskoi s'emke chetvertichnyh otlozhenii (Guide to study and geological survey of Quarternary deposits). Leningrad, Nedra, 1987, 308 pp.
15. Metody izucheniya osadochnyh porod (methods of study of sedimentary rocks). Moscow, Gosgeoltehizdat, 1957, V. 2, $564 \mathrm{pp}$.

16. Nikiforova L. D. Dinamika landshaftnyh zon golotsena Severo-Vostoka Evropeiskoi chasti SSSR (Dynamics of landscape zones of Holocene in north-western part of European USSR). In: Razvitie prirody territorii SSSR v pozdnem pleistotsene i golotsene (Development of nature of USSR area in Late Pleistocene and Holocene). Moscow, Nauka, 1982, pp. 154-162.

17. Ovodov N. D. Paleofaunisticheskoe izuchenie pescher (Paleofaunistical study of caves). In: Obschie metody izucheniya istorii sovremennyh ekosistem (General methods of study of history of modern ecosystems). Moscow, Nauka, 1979, pp. 102128.

18. Smirnov N. G. Dinamika vidov $i$ ih kompleksov kak predmet issledovanii istoricheskoi ekologii (Species and their complexes dynamics as object of historical ecology). Ekologiya, 2006, No. 6, pp. 452-456.

19. Smirnov N. G., Golovachev I. B., Bachura O. P., Kuznetsova I. A., Cheprakov M. I. Slozhnye sluchai opredeleniya zubov gryzunov iz otlozhenii pozdnego pleistotsena i golotsena tundrovyh raionov Severnoi Evrazii (Problems of determination of gnawer species from Late Pleistocene and Holocene deposits of Eurasia tundra). In: Materialy po istorii i sovremennomu sostoyaniyu fauny severa Zapadnoi Sibiri (Materials on history and modern state of fauna of northern Western Siberia). Chelyabinsk, 1997, pp. $60-90$.

20. Smirnov N. G., Sadykova N. O. Istochniki pogreshnostei pri faunisticheskih rekonstruktsiyah $v$ chetvertichnoi paleozoologii (Sources of errors at faunistical reconstructions in Quarternary paleozoology). In: Chetvertichnaya paleozoologiya na Urale (Quarternary paleozoology in Urals). Ekaterinburg, 2003, pp. 98-115.

21. Tureva V. V. Ekologo-faunisticheskii obzor melkih mlekopitayuschih zapadnogo sklona Pripolyarnogo Urala (Ecological faunistical review of small mammals of western slope of SUbpolar Urals). In: Zhivotnyi mir zapadnogo sklona Pripolyarnogo Urala (Animal world of western slope of Subpolar Urals). Syktyvkar, 1977, pp. 44-101.

22. Fauna evropeiskogo Severo-Vostoka Rossii. Mlekopitayuschie (Fauna of European north-east of Russia. Mammals). V. II. part 1. St-Petersburg, Nauka, 1994, 280 pp.

23. Mayhew D. F. Avian predators as accumulators of fossil mammal material. Boreas. 1977, V. 6, No. 1, pp. 25-31. 